\title{
Traumatismo genital
}

\author{
Martín Martín S, Torrecilla García-Ripoll JR, Sanz Ruiz A, Gonzalo Rodríguez V, \\ Müller Arteaga C, Fernández del Busto E.
}

Servicio de Urología. Hospital Clínico Universitario de Valladolid.

Actas Urol Esp. 2007;31(7):800

$\mathrm{P}$ aciente que acude a urgencias por accidente de tráfico, tras ser atropellado por un tractor. A la exploración, se aprecia importante contusión en región genital, con aplastamiento de pene y escroto. Quemaduras de tercer grado en cara interna de muslo derecho con amplias zonas de necrosis e importante edema. Los pulsos femorales están conservados y no se encuentran signos de trombosis venosa profunda en Eco-doppler.

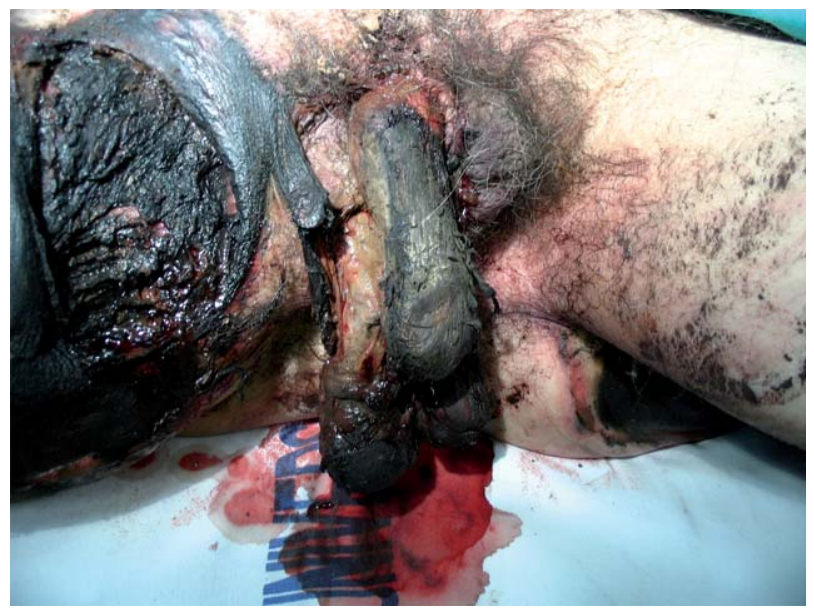

FIGURA 1. Aplastamiento escrotal y de pene, con quemaduras de tercer grado en cara interna de muslo de pierna derecha.
Se practica desbridamiento quirúrgico de zonas necróticas hasta alcanzar tejido sano y sondaje vesical.

El paciente se deriva a Servicio de Cirugía Plástica para reparación.

Correspondencia autor: Dr. S. Martín Martín

Servicio de Urología. Hospital Clínico Universitario de Valladolid.

Ramón y Cajal, s/n - 47005 Valladolid. Tef.: 983420000

E-mail autor: risimartin7@hotmail.com

Información artículo: Imágenes en Urología

Trabajo recibido: mayo 2006

Trabajo aceptado: junio 2006

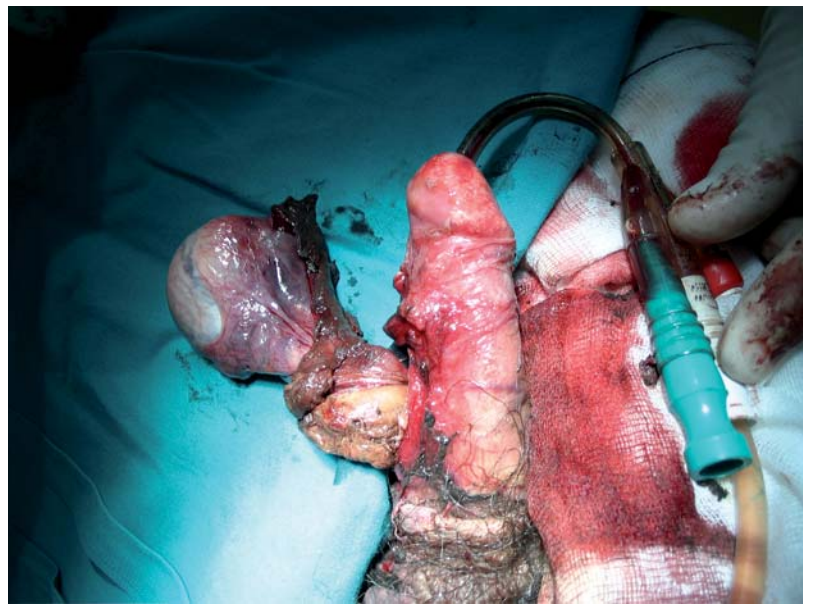

FIGURA 2. Desbridamiento y sondaje vesical. 